\title{
Women Street Vendors, Challenges and Opportunities: An Superlative Analysis with Special Reference to Chittoor District of Andhra Pradesh, India
}

\author{
R. Vara Prasad, D. Subhashini
}

\begin{abstract}
Informal Sector is the most important part of the workforce in India and other developing countries works. It has become a progressively more popular subject of study, not just in economics, but also in Social Work, Sociology and Anthropology. The term of "Informal Sector" was first coined by Keith Hart. There are many informal sectors in our country working for their own livelihood. The most frequently and regularly they must work to earn their daily bread Street Vending is a major self-employment provider in and around the world. It is an occupation perused by the middle and lower middle class as a full time and part time employment for source of living. There is very few number of studies being conducted on street vendors. The present study is undertaken to project the various issues that the women street vendors face in their everyday occupation. In men dominated society women are always considered to be inferior and there are number of cases of harassment and abuse which not only make women to leave their bread earning occupation but also suffer financial loss. The present study comes at a time when the living and working environment for women are deteriorating; this study presents the various issues and problems faced by women street vendors.
\end{abstract}

Index Terms: Women street vendors, economic conditions, informal sector, reasons for street vending

\section{INTRODUCTION}

A street vendor is somebody who offers goods or services for garage sale to the public without having an always built meeting but with a temporary static structure or mobile stall (or head-load). The Government of India has used the term urban vendor as complete of both traders and service providers, stationary as well as mobile, and incorporates all other local/region specific terms used to describe them, such as, hawker, pheriwalla, rehri-patriwalla, footpath dukandars, sidewalk traders, and more. Street vendors have been in existence since ancient times. In all civilizations, ancient and medieval, one reads accounts of travelling merchants who not only sold their wares in the town by going from house to house but they also traded in neighboring countries. Perhaps ancient and medieval civilizations were tolerant to these wandering traders and that is why they flourished. In modern times we find that street vendors are rarely treated with the same measure of dignity and tolerance.

Revised Manuscript Received on July 22, 2019

Dr. R. Vara Prasad, Assistant Professor, School of Management Studies, REVA University, Bengaluru, India

D. Subhashini, Lecturer in Commerce, SSGS Aided Degree College, Guntakal and Research Scholar, SKIM, SK University, Anantapuramu, Andhra Pradesh, India
For most street vendors, trading from the pavements is full of uncertainties. They are constantly harassed by the authorities. The local bodies conduct eviction drives to clear the pavements of these encroachers and in most cases confiscate their goods.. Confiscation of their goods entails heavy fines for recovery. In most cases it means that the vendor has to take loans from private sources (at exorbitant interests) to either recover whatever remains of his confiscated goods or to restart his business.

Besides these sudden raids, street vendors normally have to regularly bribe the authorities in order to carry out their business on the streets. All these mean that a substantive income from street vending is spent on greasing the palms of unscrupulous authorities or to private money lenders. In fact in most cases street vendors have to survive in a hostile environment though they are service providers.

\section{LITEARTURE REVIEW}

Dipak Bahadur Adhikari (2011) Street vending comes under informal sector it came into existence from 1970s.street vending requires less investment and income from that can satisfy only their basic needs. Income from street vending is less but more people involved in street vending. If we compare with other sectors activities profits are very less in street vending. Mostly people who are involved in street vending due to less employment opportunities in other sectors and people comes under agricultural sector as they possesses a small area of land to cultivate to earn for their livelihood.

Ar. Manojpanwar, Vikas Garg (2015) provided evidence that there are very less women street vendors and there are facing the stress that there are less people visiting them and they fell that right to livelihood need to be protected. Vendors should form association recommendation and forwarding of applications for registration of all existing vendors to district administration in fair and transparent manner. District administration should issue vending license and proof of identity to carry out vending in specific areas thereby making the vending legal. Skill training and credit facilities to be made available to street make initial investment. Schemes like pension, health care etc. should also be extended to street vendors.

Satyaki Sarkar (2016) the street vendors have no other means of livelihood, they too have no option but to carry on with their trade in this deplorable state of affairs, even if it means facing atrocious and harassment from the administration who have a vested interest in keeping the




vendors insecure and groveling. Street vendors create environmental hazards by accumulating huge garbage. They usually shift locations according to their seasons and products wanted.

Jeemol Unni and Uma Rani (2004) informal sector that is street vending growing in south Asian countries. They find evidence that large portion of street vendors in some cities of India are declining among them mostly Women. However, in the various components of informal economy were increasing and there is a growth in participation of women in them are observed. Informal employment helps women to reduce their poverty.

Otoo et al. (2009) analyzed women entrepreneurship in West Africa he found that women mostly involved in street food sector. These people earning more income than the legal wage in Niamey and Kumasi. These people prefer providing employment to other people but they are not interested in dependent workers. Income that they earn from street vending they spend for their children's education, health and other needs of family members. Street vendors always involved in street vending as a temporary one always find new opportunities to expand their business. Women street food is important avenues for employment and income generation.

Debdulal Saha (2016) Analyzed that street vendors depends on money lenders for money at the interest of 5-10 percent and finally they fall into the trap of depth. He found that there is no safety for street vendors in work place. Street vendors are working hard for 14-18 hours. Street vendors are facing many problems like harassment from authorities of Municipal Corporation and police. Trade unions are not helping them only few helps in these organizations.

Winnie V. Mitullah (2003) Organization of street vendors is a pre-requisite for any success. Organized entities can contribute to effective provision and management of vending sites as is happening in some areas in South Africa. The street vendors are many and operate in different sites, and urban authorities cannot afford to employ enough officers to manage the activity. Instead, self-management supported by urban authorities should be encouraged.

R. Karthikeyan and R. Mangaleswaran (2013)Street Vendors are the integral part of human society. These people are to be looked after by the individuals, group and communities. Even though they have this type of occupation, their day-to-day life is not safe. Government should take activelroles to implement the policies effectively, which they have made. Hence, the government should look in to the problems of the street vendor's each corner of life. As professional social workers, it is our duty and obligation to work for the well-being of the Street Vendors.

\section{NEED FOR THE STUDY}

Street Vending is a major self-employment provider in and around the world. It is an occupation perused by the middle and lower middle class as a full time and part time employment for source of living. There is very few number of studies being conducted on street vendors. The present study is undertaken to project the various issues that the women street vendors face in their everyday occupation. In a men dominated society women are always considered to be inferior and there are number of cases of harassment and abuse which not only make women to leave their bread earning occupation but also suffer financial loss.

The present study comes at a time when the living and working environment for women are deteriorating; this study presents the various issues and problems faced by women street vendors.

\section{STATEMENT OF PROBLEM}

Street vendors are considered as informal sector which is very important factor of the trade association in the war.

The women street vendor gets the quality of life through their occupation because they are not developed in their life style. (R. Karthikeyan \& R. Mangaleswaran Dec 2013)

In the present study we are dealing with women street vendors

1. Socio-economic profile

2. Reasons for street vending

3. To understand the awareness levels of women street vendors regarding their basic rights and policies

4. Financial accessibility\& financial credit.

\section{A. OBJETIVES}

1. To identify personal and socio-economic profile of women street vendors.

2. To investigate the causes responsible for street vending.

3. To understand the awareness level of women street vendors on various government entrepreneurial policies and their rights.

4. To understand the financial accessibility including institutional credit.

\section{B. HYPOTHESIS}

1. H1: There is no relationship between the women street vendors age with respect to experience.

2. H2: There is no relationship between the women street vendor's investment needed for a day with respect to income generated on daily basis.

3. H3: There is no relationship between the women street vendor's investment needed for a day with respect to loss incur on daily basis

4. H4: There is no relationship between the women street vendors trained on health precaution measures to be taken while selling with respect to Health impacted by pollution during street vending

5. H5: There is no relationship between the women street vendors working hours with respect to income generate on daily basis.

\section{SOURCE OF DATA}

Primary data was collected from 115 respondents of Madanapalle and Tirupati towns of Chittoor District using convenience sampling method.

\section{SAMPLE DESIGN}

1. Sampling Frame: All the street vendors of Madanapalle and Tirupati town

2. Sampling Unit: women street vendors who are engaged in selling goods by sitting and trolley

3. Sampling size: 115

4. Sampling Method: Convenience sampling 


\section{E. STATISTICAL TOOL USED}

1. SPSS 20 had been used to draw the results.

2. Factor analysis used to minimize the components

3. Chi-square method is adopted to draw inferences based on the questionnaire

4. Chart builder is used to the exact positions of women street vendor

\section{SCOPE OF THE STUDY}

The study gives emphasis on socio-economic analysis of the vendors and identifies appropriate strategy to include street vending into rural system. However given the complexity of street vending and diversity of individual circumstances suggesting any generalized solution to the existing problem for a large and growing district like Chittoor is quite difficult task

\section{LIMITATIONS}

1. While answering the questionnaire the other street vendors are influencing the opinions of other respondents

2. The study focused on sitting and trolley women street vendors only

3. The data was collected through questionnaire and there is a possibility of omission of replies

4. Most of the respondents are not answering the financial aspects which are their in the questionnaire Table 1: Age of women street vendors

\begin{tabular}{|c|c|c|c|}
\hline S.No & $\begin{array}{c}\text { Age (in } \\
\text { years) }\end{array}$ & $\begin{array}{c}\text { No. of Women } \\
\text { Street Vendors }\end{array}$ & Percentage \\
\hline 1 & $21-30$ & 14 & $12 \%$ \\
\hline 2 & $31-40$ & 36 & $31 \%$ \\
\hline 3 & $41-50$ & 37 & $32 \%$ \\
\hline 4 & $51-60$ & 25 & $22 \%$ \\
\hline
\end{tabular}

Interpretation: From the above chart it is understood that $32 \%$ of women street vendors are aged between $41-50$ years where as $12 \%$ are aged between 21-30 years and minimum $3 \%$ aged between $61-70$

Table 2: Native Place of women street vendors

\begin{tabular}{|c|c|c|c|}
\hline S.No & Native Place & $\begin{array}{c}\text { No. of } \\
\text { Women } \\
\text { Street } \\
\text { Vendors }\end{array}$ & Percentage \\
\hline 1 & Thirupathi & 51 & $45.35 \%$ \\
\hline 2 & Madanapalle & 64 & $55.65 \%$ \\
\hline & TOTAL & 115 & $100 \%$ \\
\hline
\end{tabular}

Interpretation: From the above chart we can understand that $55.65 \%$ (64 members) belongs to Madanapalle, whereas $45.35 \%$ (51 members) belongs to Thirupathi.

Table 3: Educational qualification of women street

\begin{tabular}{|c|c|c|c|}
\hline S.No & $\begin{array}{c}\text { Educational } \\
\text { Qualification }\end{array}$ & $\begin{array}{c}\text { No. of } \\
\text { Women } \\
\text { Street } \\
\text { Vendors }\end{array}$ & Percentage \\
\hline 1 & $5^{\text {th }}$ Class & 6 & $5.22 \%$ \\
\hline 2 & $10^{\text {th }}$ Class & 6 & $5.22 \%$ \\
\hline 3 & Intermediate & 5 & $5.34 \%$ \\
\hline 4 & None & 98 & $85.22 \%$ \\
\hline & TOTAL & 115 & $100 \%$ \\
\hline
\end{tabular}

Interpretation: From the above chart it is understood that most of the women street vendors are uneducated 85.22\% (98 members) where as $5.22 \%$ completed their $5^{\text {th }} \& 10^{\text {th }}$ class respectively.
Table 4: Marital status of women street vendors

\begin{tabular}{|c|c|c|c|}
\hline S.No & $\begin{array}{c}\text { Marital } \\
\text { Status }\end{array}$ & $\begin{array}{c}\text { No. of } \\
\text { Women } \\
\text { Street } \\
\text { Vendors }\end{array}$ & Percentage \\
\hline 1 & Married & 96 & $83.48 \%$ \\
\hline 2 & Widow & 19 & $16.52 \%$ \\
\hline & TOTAL & 115 & $100 \%$ \\
\hline
\end{tabular}

Interpretation: From the above chart we can understand that $83.48 \%$ (96members) of women street vendors are married where as $16.52 \%$ (19 members) are widow

Table 5: Dependents in family

\begin{tabular}{|c|c|c|c|}
\hline S.No & $\begin{array}{c}\text { No. Of } \\
\text { Dependents }\end{array}$ & $\begin{array}{c}\text { No. of } \\
\text { Women } \\
\text { Street } \\
\text { Vendors }\end{array}$ & Percentage \\
\hline 1 & 0 & 6 & $3.48 \%$ \\
\hline 2 & 1 & 31 & $26.96 \%$ \\
\hline 3 & 2 & 41 & $35.65 \%$ \\
\hline 4 & 3 & 17 & $15.78 \%$ \\
\hline 5 & 4 & 14 & $12.17 \%$ \\
\hline 6 & 5 & 8 & $6.96 \%$ \\
\hline & TOTAL & 115 & $100 \%$ \\
\hline
\end{tabular}

Interpretation: From the above chart it is understood that women street vendors dependents in family of 2 more i.e.., $35.65 \%$ whereas 6 i.e.., $3.48 \%$ women street vendors are not having no dependents in family

Table 6: Religion

\begin{tabular}{|c|c|c|c|}
\hline S.No & Religion & $\begin{array}{c}\text { No. of Women } \\
\text { Street } \\
\text { Vendors }\end{array}$ & Percentage \\
\hline 1 & Hindu & 101 & $87.83 \%$ \\
\hline 2 & Muslim & 14 & $12.17 \%$ \\
\hline & TOTAL & 115 & $100 \%$ \\
\hline
\end{tabular}

Interpretation: From above chart it is understood that most of the women street vendors $87.83 \%$ (101 members) belongs to Hindu region where as $12.17 \%$ (14 members) are Muslims

Table 7: Community

\begin{tabular}{|c|c|c|c|}
\hline S.No & Community & $\begin{array}{c}\text { No. of } \\
\text { Women } \\
\text { Street } \\
\text { Vendors }\end{array}$ & Percentage \\
\hline 1 & BC & 78 & $67.83 \%$ \\
\hline 2 & MBC & 20 & $17.39 \%$ \\
\hline 3 & SC & 14 & $12.17 \%$ \\
\hline 4 & ST & 3 & $2.61 \%$ \\
\hline & TOTAL & 115 & $100 \%$ \\
\hline
\end{tabular}

Interpretation: From the above chart we can understand that women street vendors most of them belongs to $\mathrm{BC}$ community $67.83 \%$ (78 members) where as MBC $17.38 \%$, SC $12.17 \%$ and minimum from ST $2.61 \%$ (3 members). 
Women Street Vendors, Challenges and Opportunities: An Superlative Analysis with Special Reference to Chittoor District of Andhra Pradesh, India

Table 8: How long been into street vending

\begin{tabular}{|c|c|c|c|}
\hline S.No & $\begin{array}{c}\text { Experience (in } \\
\text { years) }\end{array}$ & $\begin{array}{c}\text { No. of } \\
\text { Women } \\
\text { Street } \\
\text { Vendors }\end{array}$ & Percentage \\
\hline 1 & $3-5$ Years & 32 & $27.83 \%$ \\
\hline 2 & Above 5 Years & 83 & $72.17 \%$ \\
\hline & TOTAL & 115 & $100 \%$ \\
\hline
\end{tabular}

Interpretation: From the above chart we can understand that most of the women street vendors have experience more than 5 years i.e.., $72.17 \%$ ( 83 members) where as $27.83 \%$ ( 32 members) have experience from 3-5 years.

Table 9: Type of product women street vendor sell

\begin{tabular}{|c|c|c|c|}
\hline S.No & Product & $\begin{array}{c}\text { No. of } \\
\text { Women } \\
\text { Street } \\
\text { Vendors }\end{array}$ & Percentage \\
\hline 1 & Vegetables & 83 & $72.17 \%$ \\
\hline 2 & $\begin{array}{c}\text { Vegetables } \\
\& \text { Fruits }\end{array}$ & 8 & $6.96 \%$ \\
\hline 3 & Fruits & 8 & $6.96 \%$ \\
\hline 4 & Others & 16 & $13.91 \%$ \\
\hline & TOTAL & 115 & $100 \%$ \\
\hline
\end{tabular}

Interpretation: From the above chart we can understand that most of the women street vendors sell vegetables $72.17 \%$ (83 members) where as others $6.96 \%$ ( 8 members) person sell fruits, vegetables \& fruits, $13.91 \%$ ( 16 members) sell other products respectively.

Table 10: Sales pattern

\begin{tabular}{|c|c|c|c|}
\hline S.No & Product & $\begin{array}{c}\text { No. of } \\
\text { Women } \\
\text { Street } \\
\text { Vendors }\end{array}$ & Percentage \\
\hline 1 & Sitting & 99 & $86.09 \%$ \\
\hline 2 & Trolley & 16 & $13.91 \%$ \\
\hline & TOTAL & 115 & $100 \%$ \\
\hline
\end{tabular}

Interpretation: From the above we can understand that women street vendors sell their products by sitting i.e.., $86.09 \%$ (99 members) where as others sell their products through trolley i.e.., $13.91 \%$ (16 members)

Table 11: Family members engaged in street vending

\begin{tabular}{|c|c|c|c|}
\hline S.No & $\begin{array}{c}\text { Is family } \\
\text { members } \\
\text { engaged in } \\
\text { street } \\
\text { vending }\end{array}$ & $\begin{array}{c}\text { No. of } \\
\text { Women } \\
\text { Street } \\
\text { Vendors }\end{array}$ & Percentage \\
\hline 1 & Yes & 39 & $33.91 \%$ \\
\hline 2 & No & 76 & $66.09 \%$ \\
\hline & TOTAL & 115 & $100 \%$ \\
\hline
\end{tabular}

Interpretation: From the above chart, we can understand that most of the women street vendors' family members are not engaged in street vending i.e.., 66.09\% (76 members) where as $33.91 \%$ (39 members) are engaged in street vending.
Table 11.1: How many family members are engaged in street vending

\begin{tabular}{|c|c|c|c|}
\hline S.No & $\begin{array}{c}\text { Is family } \\
\text { members } \\
\text { engaged in } \\
\text { street vending }\end{array}$ & $\begin{array}{c}\text { No. of } \\
\text { Women } \\
\text { Street } \\
\text { Vendors }\end{array}$ & Percentage \\
\hline 1 & 1 Member & 21 & $53.85 \%$ \\
\hline 2 & 2 Members & 12 & $30.77 \%$ \\
\hline 3 & 3 Members & 0 & $0 \%$ \\
\hline 4 & 4 Members & 6 & $15.36 \%$ \\
\hline & TOTAL & 39 & $100 \%$ \\
\hline
\end{tabular}

Interpretation: Fro the above chart we can understand that 1 family member is engaged in street vending i.e.., $53.85 \%$ (21 members of 39) where as $30.77 \%$ of 2 members and 4 members of $15.36 \%$.

Table 11.2: Mode of travel

\begin{tabular}{|c|c|c|c|}
\hline S.No & $\begin{array}{c}\text { Mode Of } \\
\text { Travel }\end{array}$ & $\begin{array}{c}\text { No. of } \\
\text { Women } \\
\text { Street } \\
\text { Vendors }\end{array}$ & Percentage \\
\hline 1 & Bus & 30 & $26.09 \%$ \\
\hline 2 & Train & 0 & $0 \%$ \\
\hline 3 & $\begin{array}{c}\text { Auto } \\
\text { rickshaw }\end{array}$ & 46 & $40 \%$ \\
\hline 4 & By Walk & 39 & $33.91 \%$ \\
\hline & TOTAL & 115 & $100 \%$ \\
\hline
\end{tabular}

Interpretation: From the above chart we can understand that women street vendors mostly travel through Auto rickshaw i.e.., $40 \%$ (46 members) where as others travel through bus $26.09 \%$ ( 30 members) and $33.91 \%$ (39 members) reach vending place by walk.

Table 11.3: Working hours

\begin{tabular}{|c|c|c|c|}
\hline S.No & $\begin{array}{c}\text { Working } \\
\text { Hours(in } \\
\text { hrs) }\end{array}$ & $\begin{array}{c}\text { No. of } \\
\text { Women } \\
\text { Street } \\
\text { Vendors }\end{array}$ & Percentage \\
\hline 1 & $2-3$ Hours & 0 & $0 \%$ \\
\hline 2 & $3-4$ Hours & 10 & $8.7 \%$ \\
\hline 3 & $4-5$ Hours & 10 & $8.7 \%$ \\
\hline 4 & $5-6$ Hours & 59 & $51.30 \%$ \\
\hline 5 & 6-8 Hours & 36 & $31.3 \%$ \\
\hline & TOTAL & 115 & $100 \%$ \\
\hline
\end{tabular}

Interpretation: From the above chart we can understand that women street vendors most of them work for 5-6 hours i.e.., $51.30 \%$ (59 members) where as others work for 6-8 hours $31.30 \%$ ( 36 members) and others work for 3-4 hours \& 4-5 hours $8.70 \%$ (10 members) respectively.

Table 11.4: Working members in family

\begin{tabular}{|c|c|c|c|}
\hline S.No & $\begin{array}{c}\text { Working } \\
\text { Members In } \\
\text { Family }\end{array}$ & $\begin{array}{c}\text { No. of } \\
\text { Women } \\
\text { Street } \\
\text { Vendors }\end{array}$ & Percentage \\
\hline 1 & 1 Member & 56 & $48.70 \%$ \\
\hline 2 & $2-3$ Members & 59 & $51.30 \%$ \\
\hline 3 & $4-5$ Members & 0 & $0 \%$ \\
\hline & TOTAL & 115 & $100 \%$ \\
\hline
\end{tabular}

Interpretation: From the above chart we can understand that women street vendors family working members mostly are 2-3 members $48.70 \%$ ( 56 members) where as others 1 member are $48.70 \%(56$ members) 
Table 11.5: Investment on daily basis

\begin{tabular}{|r|c|c|c|}
\hline S.No & Investment(INR) & $\begin{array}{c}\text { No. of } \\
\text { Women } \\
\text { Street } \\
\text { Vendors }\end{array}$ & \\
\hline 1 & $200-600$ & 10 & $8.7 \%$ \\
\hline 2 & $600-1000$ & 40 & $35.78 \%$ \\
\hline 3 & $1000-1400$ & 18 & $15.65 \%$ \\
\hline 4 & $1400-1800$ & 37 & $32.17 \%$ \\
\hline 5 & MoreThan 1800 & 10 & $8.7 \%$ \\
\hline & TOTAL & 115 & $100 \%$ \\
\hline
\end{tabular}

Interpretation: From the above chart we understand that women street vendors invest $600-1000$ of $35.78 \%(40$ members) and others $1400-1800$ of $32.17 \%, 1000-1400$ of $15.65 \% .200-600$ of $8.7 \%$ and more than 1800 of $8.7 \%$ respectively on daily basis.

Table 11.6: Income generated every day

\begin{tabular}{|c|c|c|c|}
\hline S.No & Income(INR) & $\begin{array}{c}\text { No. of } \\
\text { Women } \\
\text { Street } \\
\text { Vendors }\end{array}$ & Percentage \\
\hline 1 & $50-100$ & 0 & 0 \\
\hline 2 & $100-150$ & 16 & $13.91 \%$ \\
\hline 3 & $150-200$ & 70 & $60.87 \%$ \\
\hline 4 & $200-300$ & 0 & $0 \%$ \\
\hline 5 & More than 300 & 29 & $25.22 \%$ \\
\hline & TOTAL & 115 & $100 \%$ \\
\hline
\end{tabular}

Interpretation: From the above chart we can understand that women street vendors generate income on daily basis $100-150$ of $13.91 \%$ (16 members), $150-200$ of $60.87 \%$ ( 70 members) and more than 300 of $25.22 \%$ ( 29 members).

Table 11.7: Loss incur on daily basis

\begin{tabular}{|c|c|c|c|}
\hline S.No & $\begin{array}{c}\text { Loss } \\
\text { Incur(INR) }\end{array}$ & $\begin{array}{c}\text { No. of } \\
\text { Women } \\
\text { Street } \\
\text { Vendors }\end{array}$ & Percentage \\
\hline 1 & Less than 200 & 30 & $26.09 \%$ \\
\hline 2 & Less than 300 & 56 & $48.7 \%$ \\
\hline 3 & Less than 400 & 9 & $7.83 \%$ \\
\hline 4 & Less than 500 & 10 & $8.7 \%$ \\
\hline 5 & 500 and Above & 10 & $8.7 \%$ \\
\hline & TOTAL & 115 & $100 \%$ \\
\hline
\end{tabular}

Interpretation: From the above chart we can understand that women street vendors incur losses on the daily basis $48.70 \%$ incur loss less than 300 (56 members), $26.09 \%$ of less than 200 (30 members) $8.70 \%$ of less than 500 and 500 and above (10 members) and $7.83 \%$ less than 400 (9 members).

Table 11.8: Remaining goods on daily basis

\begin{tabular}{|c|c|c|c|}
\hline S.No & $\begin{array}{c}\text { Remaining } \\
\text { Goods }\end{array}$ & $\begin{array}{c}\text { No. of } \\
\text { Women } \\
\text { Street } \\
\text { Vendors }\end{array}$ & Percentage \\
\hline 1 & $\begin{array}{c}\text { Sell on Next } \\
\text { day }\end{array}$ & 95 & $82.61 \%$ \\
\hline 2 & $\begin{array}{c}\text { Sell off at a } \\
\text { discount }\end{array}$ & 10 & $8.7 \%$ \\
\hline 3 & $\begin{array}{c}\text { Dispose the } \\
\text { goods }\end{array}$ & 10 & $8.7 \%$ \\
\hline & TOTAL & 115 & $100 \%$ \\
\hline
\end{tabular}

Interpretation: From the above chart we can observed that women street vendors mostly they sell their products on next day $82.61 \%$ (95 members) others sell of at a discount and dispose the goods $8.7 \%$ ( 10 members) respectively.
Table 12: Source of capital

\begin{tabular}{|c|c|c|c|}
\hline S.No & $\begin{array}{c}\text { Source of } \\
\text { Capital }\end{array}$ & $\begin{array}{c}\text { No. of } \\
\text { Women } \\
\text { Street } \\
\text { Vendors }\end{array}$ & Percentage \\
\hline 1 & Own Savings & 58 & $50.43 \%$ \\
\hline 2 & $\begin{array}{c}\text { Loan from } \\
\text { Merchants }\end{array}$ & 37 & $32.17 \%$ \\
\hline 3 & $\begin{array}{c}\text { Loan from } \\
\text { Family and } \\
\text { Friends }\end{array}$ & 20 & $17.39 \%$ \\
\hline 4 & Loan from NGO & 0 & $0 \%$ \\
\hline 5 & Others & 0 & $0 \%$ \\
\hline & TOTAL & 115 & $100 \%$ \\
\hline
\end{tabular}

Interpretation: From the above chart we can observe that women street vendors source of capital $50.43 \%$ (58 members) invest their own savings where as others $32.17 \%$ (37 members) take loan from merchant and others $17.39 \%$ (20 members) take loan from family and friends.

Table 13: Residential status

\begin{tabular}{|c|c|c|c|}
\hline S.No & $\begin{array}{c}\text { Residential } \\
\text { Status }\end{array}$ & $\begin{array}{c}\text { No. of } \\
\text { Women } \\
\text { Street } \\
\text { Vendors }\end{array}$ & Percentage \\
\hline 1 & Self-own house & 28 & $25.35 \%$ \\
\hline 2 & Rented house & 87 & $75.65 \%$ \\
\hline & TOTAL & 115 & $100 \%$ \\
\hline
\end{tabular}

Interpretation: From the above chart we observed that women street vendors most of them live in rented house i.e.., $75.65 \%$ ( 87 members) and others $25.35 \%$ (28 members) live in self-own house.

Table 14: Reason to choose street vending

\begin{tabular}{|c|c|c|c|}
\hline S.No & $\begin{array}{c}\text { Reason for } \\
\text { choosing street } \\
\text { vending }\end{array}$ & $\begin{array}{c}\text { No. of } \\
\text { Women } \\
\text { Street } \\
\text { Vendors }\end{array}$ & Percentage \\
\hline 1 & To lead a basic life & 66 & $57.39 \%$ \\
\hline 2 & $\begin{array}{c}\text { To meet the } \\
\text { financial problems }\end{array}$ & 39 & $33.91 \%$ \\
\hline 3 & $\begin{array}{c}\text { Due to } \\
\text { unemployment }\end{array}$ & 10 & $8.7 \%$ \\
\hline 4 & $\begin{array}{c}\text { Due to passion in } \\
\text { art }\end{array}$ & 0 & $0 \%$ \\
\hline & TOTAL & 115 & $100 \%$ \\
\hline
\end{tabular}

Interpretation: From the above chart we observed that women street vendors choose street vending 57.39\% (66 members) to lead a basic life, $33.91 \%$ (39 members) to meet the financial problems and others for due to unemployment i.e.., $8.70 \%$ (10 members) 
Women Street Vendors, Challenges and Opportunities: An Superlative Analysis with Special Reference to Chittoor District of Andhra Pradesh, India

Table 15: Awareness about license for sale in public places \&license

\begin{tabular}{|c|c|c|c|}
\hline S.No & $\begin{array}{c}\text { Awareness } \\
\text { about license } \\
\text { and licensed }\end{array}$ & $\begin{array}{c}\text { No. of } \\
\text { Women } \\
\text { Street } \\
\text { Vendors }\end{array}$ & Percentage \\
\hline 1 & Yes & 30 & $26.09 \%$ \\
\hline 2 & No & 85 & $73.91 \%$ \\
\hline & TOTAL & 115 & $100 \%$ \\
\hline
\end{tabular}

Interpretation: From the above chart we observed that women street vendors most of them are not aware and not licensed $73.91 \%$ others $26.09 \%$ (30 members) of them aware and having license.

Table 16: Having a bank account

\begin{tabular}{|c|c|c|c|}
\hline S.No & $\begin{array}{c}\text { Having } \\
\text { bank } \\
\text { account }\end{array}$ & $\begin{array}{c}\text { No. of } \\
\text { Women } \\
\text { Street } \\
\text { Vendors }\end{array}$ & Percentage \\
\hline 1 & Yes & 85 & $73.91 \%$ \\
\hline 2 & No & 30 & $26.09 \%$ \\
\hline & TOTAL & 115 & $100 \%$ \\
\hline
\end{tabular}

Interpretation: From the above chart we observed that women street vendors most of them have bank account i.e.., $73.91 \%$ ( 85 members) and others $26.09 \%$ (30 members) doesn't have bank account.

Table 16.1: Type of bank

\begin{tabular}{|c|c|c|c|}
\hline S.No & Bank & $\begin{array}{c}\text { No. of } \\
\text { Women } \\
\text { Street } \\
\text { Vendors }\end{array}$ & Percentage \\
\hline 1 & Public bank & 75 & $88.24 \%$ \\
\hline 2 & Private bank & 0 & $0 \%$ \\
\hline 3 & $\begin{array}{c}\text { Co-operative } \\
\text { bank }\end{array}$ & 10 & $11.76 \%$ \\
\hline & TOTAL & 85 & $100 \%$ \\
\hline
\end{tabular}

Interpretation: From the above chart we observed that women street vendors that $88.24 \%$ (75 among 85 ) have public bank account where as others $11.76 \%$ (10 among 85 ) process co-operative bank account

Table 16.2: Avail loan in bank

\begin{tabular}{|c|c|c|c|}
\hline S.No & BANK & $\begin{array}{c}\text { No. of } \\
\text { Women } \\
\text { Street } \\
\text { Vendors }\end{array}$ & Percentage \\
\hline 1 & Yes & 12 & $15.11 \%$ \\
\hline 2 & No & 73 & $85.89 \%$ \\
\hline & TOTAL & 85 & $100 \%$ \\
\hline
\end{tabular}

Interpretation: From the above chart we observe that 85 persons are having bank account in those 12 members avail loan i.e.., (15.11\%) others 73 doesn't avail loan (85.89\%).

Table 16.3: How many times avail loan in bank

\begin{tabular}{|c|c|c|c|}
\hline S.No & $\begin{array}{c}\text { Loan(how } \\
\text { many } \\
\text { times) }\end{array}$ & $\begin{array}{c}\text { No. of } \\
\text { Women } \\
\text { Street } \\
\text { Vendors }\end{array}$ & Percentage \\
\hline 1 & 1 time & 6 & $50 \%$ \\
\hline 2 & 2 times & 4 & $33.33 \%$ \\
\hline 3 & 3 times & 2 & $16.67 \%$ \\
\hline 4 & 4 times & 0 & $0 \%$ \\
\hline 5 & $\begin{array}{c}\text { More than } \\
4 \text { times }\end{array}$ & 0 & $0 \%$ \\
\hline & TOTAL & 12 & $100 \%$ \\
\hline
\end{tabular}

Interpretation: From the above chart we observe that women street vendors of 12 members avail bank loan among them 6 members avail loan for 1 time (50\%) others 4 members avail loan for 2 times $(33.33 \%)$ and 2 members avail loan for 3 times (16.67\%).

Table 17: Member of DWCRA group

\begin{tabular}{|c|c|c|c|}
\hline $\begin{array}{c}\text { S.N } \\
\text { o }\end{array}$ & $\begin{array}{c}\text { Member } \\
\text { of } \\
\text { DWCR } \\
\text { A }\end{array}$ & $\begin{array}{c}\text { No. of } \\
\text { Women } \\
\text { Street } \\
\text { Vendor } \\
\text { s }\end{array}$ & $\begin{array}{c}\text { Percentag } \\
\text { e }\end{array}$ \\
\hline 1 & Yes & 30 & $26.09 \%$ \\
\hline 2 & No & 85 & $73.91 \%$ \\
\hline & TOTAL & 115 & $100 \%$ \\
\hline
\end{tabular}

Interpretation: From the above chart we can observe that women street vendors most of them are members of DWCRA group $(73.91 \%) 85$ members where as others are not members of DWCRA group (26.09\%) 30 members.

Table 18: Are you suffering with any disease

\begin{tabular}{|c|c|c|c|}
\hline S.No & Disease & $\begin{array}{c}\text { No. of } \\
\text { Women } \\
\text { Street } \\
\text { Vendors }\end{array}$ & Percentage \\
\hline 1 & Blood & 20 & $17.39 \%$ \\
Pressure & Diabetes & 9 & $7.83 \%$ \\
\hline 2 & Thyroid & 20 & $17.39 \%$ \\
\hline 3 & Others & 48 & $41.74 \%$ \\
\hline 4 & None & 18 & $15.65 \%$ \\
\hline 5 & TOTAL & 115 & $100 \%$ \\
\hline
\end{tabular}

Interpretation: From the above chart we can observe that women street vendors have disease $17.39 \%$ (20 members) have blood pressure problems , 7.83\% (9 members) having diabetes, $17.39 \%$ (20 members) have thyroid, $41.74 \%$ (48 members) are having other diseases and $15.65 \%$ (18 members) are healthy.

Table 18.1: Type of Stress

\begin{tabular}{|c|c|c|c|}
\hline S.No & Types of Stress & $\begin{array}{c}\text { No. of } \\
\text { Women } \\
\text { Street } \\
\text { Vendors }\end{array}$ & Percentage \\
\hline 1 & Physical stress & 87 & $75.65 \%$ \\
\hline 2 & Financial stress & 10 & $8.7 \%$ \\
\hline 3 & $\begin{array}{c}\text { Physiological } \\
\text { stress }\end{array}$ & 8 & $6.95 \%$ \\
\hline 4 & None & 10 & $8.7 \%$ \\
\hline & TOTAL & 115 & $100 \%$ \\
\hline
\end{tabular}

Interpretation: From the above chart we can observe that women street vendors most of them having physical stress of $75.65 \% \quad$ (87 members), $6.95 \% \quad(8$ members $)$ having physiological stress and others $8.70 \%$ ( 10 members) having financial stress other $8.70 \%$ are very healthy they are having any type of stress. 


\section{Factor analysis}

Rotated Component Matrix ${ }^{\mathrm{a}}$



\begin{tabular}{|c|c|}
\hline \multicolumn{2}{|l|}{ Rotated Component Matrix ${ }^{\mathrm{a}}$} \\
\hline & Component \\
\hline & 7 \\
\hline $\begin{array}{l}\text { Is business environment secured during street } \\
\text { vending }\end{array}$ & .762 \\
\hline $\begin{array}{l}\text { Do you agree that Health impacted by } \\
\text { nollution during street vending }\end{array}$ & .083 \\
\hline Street vendors trained on health precaution & -025 \\
\hline measures to be taken while selling & \\
\hline Do you protects Products hygienically & .810 \\
\hline At the end of the day goods will remain often & .190 \\
\hline Street vending helps in meeting the basic & -.184 \\
\hline Street vending is chosen it is easy to enter & .247 \\
\hline Do you agree investment plays a key role & -.380 \\
\hline Do you poses basic facilities like drinking & .067 \\
\hline drinking facilities & .013 \\
\hline Toilets & -.012 \\
\hline parking facilities for street vendors & -.012 \\
\hline garbage collectionand solid waste disposal & -.012 \\
\hline water supply & -.012 \\
\hline
\end{tabular}

Rotated Component Matrix



Rotated Component Matrix ${ }^{\mathrm{a}}$

\begin{tabular}{|l|l|}
\hline & Component \\
\cline { 2 - 2 } & 7 \\
\hline Paying municipal commission is economical & -.236 \\
during street vending & \\
Participating in weekly markets helps street & .100 \\
vendors for selling more products & -.021 \\
Are you aware of your basic rights & \\
Are you aware about freedom to practice any & \\
profession, occupation and trade or business for & .033 \\
street vendors & \\
Are you forced by your spouse to do this \\
business?
\end{tabular}

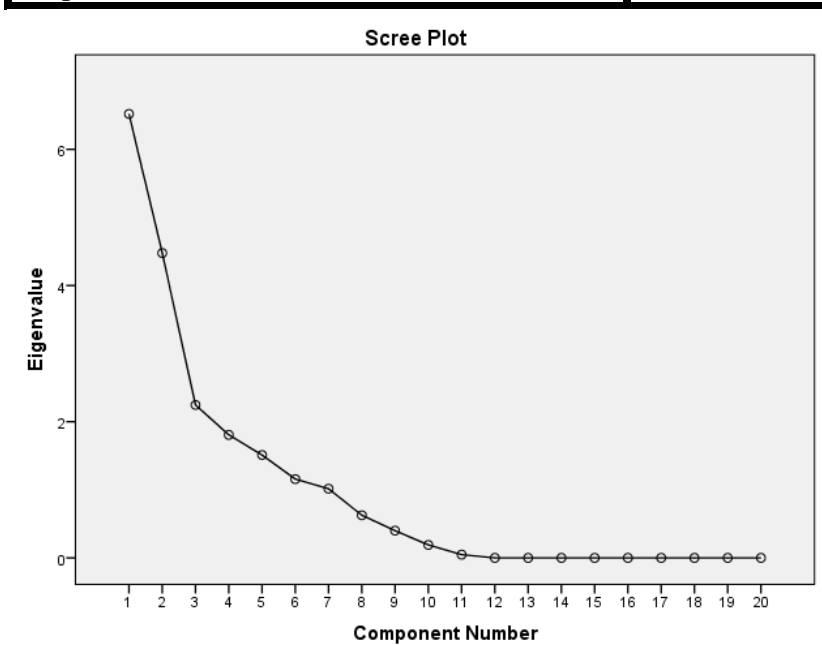

Interpretation: with the help of factor analysis 20 components reduced into 7 components

Name of the components

1. Basic facilities required for women street vendors

2. Women street vendors facing financial problems and credit facilities

3. Awareness about basic rights and policies 
4. Importance of weekly markets for selling the products by

5. Women street vendors health precautions and investment to enter into street vending

6. Family factors forces for street vending

7. Environmental secured during street vending by women street vendors.

2. Chi-square test for age of women street vendors and experience

\begin{tabular}{|c|c|c|c|}
\hline & Chi-Square Tests \\
\hline & Value & df & Asymp. Sig. (2-sided) \\
\hline Pearson Chi-Square & $121.830^{\mathrm{a}}$ & 10 & .000 \\
Likelihood Ratio & 17.053 & 10 & .073 \\
N of Valid Cases & 116 & & \\
\hline
\end{tabular}

a. 11 cells $(61.1 \%)$ have expected count less than 5 . The minimum expected count is 0.01

Inference: Hypothesis is not rejected because the significant value is more than 0.05 .

H1: There is no relationship between the women street vendors age with respect to experience.

5. Chi-square test for investment needed for a day and income generated on daily basis

Chi-Square Tests

\begin{tabular}{|l|r|r|r|}
\hline & \multicolumn{1}{|c|}{ Value } & df & Asymp. Sig. (2-sided) \\
\hline Pearson Chi-Square & $213.888^{\mathrm{a}}$ & 15 & .000 \\
Likelihood Ratio & 123.290 & 15 & .000 \\
N of Valid Cases & 116 & & \\
\hline
\end{tabular}

a.15 cells $(62.5 \%)$ have expected count less than 5 . The minimum expected count is 0.01

Inference: Hypothesis is rejected because the significant value is less than 0.05 .

H2: There is relationship between the women street vendors investment needed for a day with respect to income generated on daily basis.

6. Chi-square test for investment needed per day and loss incur on daily basis

Chi-Square Tests

\begin{tabular}{|l|r|r|r|}
\hline & \multicolumn{1}{|c|}{ Value } & df & Asymp. Sig. (2-sided) \\
\hline Pearson Chi-Square & $229.649^{\mathrm{a}}$ & 25 & .000 \\
Likelihood Ratio & 130.807 & 25 & .000 \\
N of Valid Cases & 116 & & \\
\hline
\end{tabular}

a.31 cells $(81.1 \%)$ have expected count less than 5 . The minimum expected count is 0.01

Inference: Hypothesis is rejected because the significant value is less than 0.05

H3: There is relationship between the women street vendors investment needed for a day with respect to loss incur on daily basis.

7. Chi-square test for Street vendors trained on health precaution measures to be taken while Selling and Health impacted by pollution during street vending

\begin{tabular}{|l|r|r|r|}
\hline \multicolumn{1}{|c}{ Chi-Square Tests } \\
\hline & \multicolumn{1}{|c|}{ Value } & df & Asymp. Sig. (2-sided) \\
\hline Pearson Chi-Square & $118.326^{\mathrm{a}}$ & 6 & .000 \\
Likelihood Ratio & 15.515 & 6 & .017 \\
N of Valid Cases & 116 & & \\
\hline
\end{tabular}

a.8 cells $(66.7 \%)$ have expected count less than 5 . The minimum expected count is 0.01

Inference: Hypothesis is rejected because the significant value is less than 0.05 women street vendors

H4:There is relationship between the women street vendors trained on health precaution measures to be taken while selling with respect to Health impacted by pollution during street vending.

8. Chi-square test for working hours and income generate on daily basis

Chi-Square Tests

\begin{tabular}{|l|r|r|r|}
\hline & \multicolumn{1}{|c|}{ Value } & df & Asymp. Sig. (2-sided) \\
\hline Pearson Chi-Square & $169.827^{\mathrm{a}}$ & 12 & .000 \\
Likelihood Ratio & 72.680 & 12 & .000 \\
N of Valid Cases & 116 & & \\
\hline
\end{tabular}

a.13 cells $(65.0 \%)$ have expected count less than 5 . The minimum expected count is 0.01

Inference: Hypothesis is rejected because the significant value is less than 0.05

H5: There is relationship between the women street vendors working hours with respect to income generate on daily basis.

\section{FINDINGS}

1. Women street vendors whose age is 41-50 are more in street vending in Madanapalle and Tirupathi.

2. Most of the women street vendors are uneducated and others are illiterate and studied SSLC and Intermediate.

3. Most of the women street vendors who are engaged in street vendors are married.

4. Most of the Women street vendors have 2 dependents in family.

5. Women Street vendors are mostly belong to Hindu and BC community.

6. Women street vendors who are engaged in street vending most of them have experience more than 5 years.

7. Most of the women street vendors sell vegetables and fruits by sitting in a defined place.

8. Women street vendors feel that vending environment is secure.

9. Women street vendors reach vending place through auto rickshaw

10. According to the survey, most of the women street vendors feel that health impacted by pollution during street vending.

11. According to the survey women, street vendors are not trained health precautions measures while vending.

12. Most of the women street vendors say that they sell hygienic products.

13. By the survey, we came to know that most of the women street vendors work for 5-6 hours.

14. There are more than 2 members in family who are working for their basic life.

15. Most of the women street vendors invest 600-1000 earn 150-200 and loss less than 300 on daily basis.

16. Most of the street vendors sell the remaining goods of before day on next day.

17. All the women street vendors are full time street vendors.

18. In the survey, we came to know that women street vendors invest by their own savings. 
19. Most of the women street vendors live in rented house.

20. According to the survey women, street vendors choose to lead a basic life and helps in meeting the basic needs.

21. Most of the women street vendors agree that street vending is choose it is easy to enter and investment plays a key role.

22. According to survey, we came to know that women street vendor poses basic facilities like water, toilets parking, parking facilities but they need to pay minimum charges to utilize these facilities.

23. Most of the women street vendors agree that municipal commission is economical and participating in weekly markets helps in selling more products.

24. One of the most important finding is that women street vendors are not aware about their basic rights and most of them are not aware about license and they are not licensed

25. Most of the women street vendors having bank account in public banks but only few avail loan facilities

26. Most of the women street vendors are the members of DWCRA group but they could not continue for long period because of financial instability.

27. Most of the women street vendors are not known about schemes like MUDRA

28. By the survey, we came to know that women street vendors are suffering from blood pressure, diabetes, thyroid and other diseases.

29. Women street vendors say that their spouse for street vending does not force them.

30. Most of the women street vendors are physically stress.

\section{SUGGESTIONS}

1. Most of the women street vendors are uneducated and they should need to develop the capacity when municipal commission delivering any message.

2. Women street vendors want to diversify their street vending not only vegetables and fruits they need to sell other products according to the season availability.

3. Women street vendors need to take some precautions like warring mask to avoid pollution.

4. Government should train women street vendors health precaution measures while street vending.

5. Women Street vendors need to sell products on the same day if not there is a possibility of reducing the

6. For the sake of finance, most of the women street vendors are taking loan from merchants at high interest then from merchants they can take loan from banks.

7. Women street vendors need to educate on who bank works, what are the schemes available for providing loans and the facilities enjoyed by a bank account holder.

8. Women street vendors choose street vending to lead a basic life and to meet financial problems so government can be declare as people living under below poverty line (BPL families). hygienic quality of products.

9. Women street vendors need to educate on basic facilities and policies provided by government of India.

10. The state run housing board can allocate low cost houses to women street vendors with proper toilet, drainage and drainage facilities.

11. Government of Andhra Pradesh need to get the awareness level about basic rights of women street vendors.

12. There are no such special basic rights and policies allotted to women street vendors there is a need for it.

13. Women street vendors need to educate how to get a license for street vending as most of them are not licensed.

14. Women street vendors need to educate on how to apply and get the loan from banks.

15. Government can set up counselling centres to council members street vendors as they rid of stress.

16. Regular health check can be initiated by the government for women street vendors

17. Pension scheme can be implemented by government of India for aged vendors

\section{CONCLUSION}

The work entitled "Women street vendors challenges and opportunities a study with special reference to selected cities of Chittoor district" will help us know about women street vendors in which aspects they are facing problems and there is a scope for improvement in their living. The in depth study of socio economic profile, reasons for choosing street vending, policies and rights of women street vendors in selected cities of Chittoor district has led to the unambiguous conclusion that there is a necessary action plan must be taken for the improvement in their living conditions. The study is conducted by collecting data through questionnaire making it as a primary source of data collection and various website were used for secondary data collection. After the collection of data, it was tabulated and analyzed that will help to identify their issues faced by women street vendors in day do day life. The government needs to formulate programs to address the need of women street vendors.

\section{REFERENCES}

1. Adhikari, D. B. (2012). Income generation in informal sector: A case study of the street vendors of Kathmandu Metropolitan City. Economic Journal of Development Issues, 13(0). doi:10.3126/ejdi.v13i0.7193

2. Roever, S., \& Skinner, C. (2016). Street vendors and cities. Environment and Urbanization, 28(2), 359-374. doi:10.1177/0956247816653898

3. Shalini Sinha and Sally Roever (2011).Women in Informal Employment: Globalizing and Organizing, WIEGO Policy Brief (Urban Policies) No2

4. Inclusive design for street vendors in India centre for urban equity \&amp; Cardiff University (2014)

5. Ar. Manoj Panwar and Vikas Garg (2015) Issues and challenges faced by vendors on urban on urban street, International Journal of Engineering Technology, Management and Applied Science.

6. DR. Satyaki Sarkar (2016) Street vendors in the urban care of Kolkata-problems and prospects of their rehabilitation

7. Karthikeyan, R., \& Mangaleswaran, R. (2013). Quality of Life Among Street Vendors in Tiruchirappalli City, Tamil Nadu, India International Research Journal of Social Sciences, 2(12), 18-28;

8. Karthikeyan, R., \& Mangaleswaran, R. (2014). A study on socio-economic conditions and working patterns of street vendors in

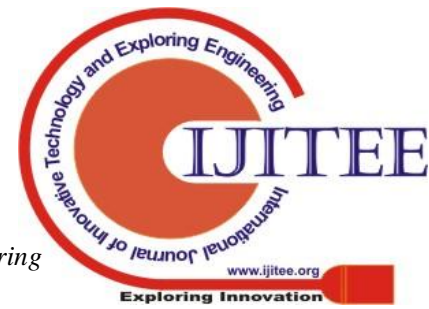


Tiruchirappalli city, Tamil Nadu, India

9. Jain, Priyank (2013), "Neoliberalizing The Streets Of Urban India: Engagements Of A Free Market Think Tank In The Politics Of Street Hawking". Theses and Dissertations--Geography. 14.

10. Tignor, R. L. (2006). W. Arthur Lewis and the birth of development economics. Princeton university press.

11. Bhowmik, Sharit K. and Debdulal Saha (2012). Street Vending in ten cities in India, National Alliance of Street Vendors of India (NASVI) 